\title{
INTELLIGENT MANAGEMENT OCCURRENCE AND SPREAD OF FRONT FIRE IN GIS BY USING CELLULAR AUTOMATA. CASE STUDY: GOLESTAN FOREST
}

\author{
S. Hesam ${ }^{1}$, Kh. ValizadehKamran ${ }^{2}$ \\ ${ }^{1}$ Dept. GIS Engineering, University Islamic Azad, Tabriz - setayesh.hesam@ gmail.com \\ ${ }^{2}$ Dept. Remote Sensing and GIS, University Tabriz, Tabriz-valizadeh@ tabrizu.ac.ir
}

Commission VI, WG VI/4

KEY WORDS: Cellular Automaton, Geospatial Information System, Wildfire, Golestan

\begin{abstract}
:
Jungles are a country's treasures, and the survival of humans and the earth depends on the oxygen that they produce (trees). Three million hectares of jungle are destroyed each year as a result of natural or human-caused wildfires. The massive wildfires occurring in the world confirms that this destructive phenomenon leaves irreconcilable effects on regional ecosystems, vegetation and wildlife; presenting more effective approaches for preventing and managing this complex phenomenon has therefore always been the focus of environmental managers and planners. In other words, it is necessary to model the spread of wildfires, which can be used for utilizing forces and equipment most effectively. Cellular automaton is considered a very simple yet highly effective method that is very capable of modeling dynamic events, like urban development, spread of wildfires, disease outbreaks and others. This study used layers such as height, slope, aspect, vegetation density, roads, rivers and climate as its basis. This was a case study of the Golestan region's jungles, which calculated the general accuracy of the wildfire spread model to be 65 percent, and the Cohen's kappa coefficient to be 59 percent.

\section{INTRODUCTION}

Today, fire in land, after urban activities and human agriculture, is the most widespread destructive factor in natural ecosystems. Fire is one of the most important factors of change in the condition of forests and pastures (Penttila et al, 2013). Due to the climate change and global warming, changes in the pattern of rainfall and climate, it has caused severe damage to natural resources (Collins et al. 2013). In fact, fire is one of the important factors in disrupting the structure and dynamics of the forest in natural conditions causing the production of a large amount of dead wood due to the destruction of trees (Shorohova et al, 2009). In a short period of time after the fire, the number of insects suddenly decreases (Swengel, 2001), and many wild animals living in the forest are affected, and vegetation, leaf litter, seed bank, and soil in the region are also subjected to change( $\mathrm{K} \mathrm{im}$ et al, 2008). Every year, there are significant costs for fire control in countries, and ecosystem management is a way to reduce the effects of fire on forests and preserve the landscape(Oliveira, 2001). To manage fire in the forest, understanding of fire behavior and its factors in an appropriate environment and factors affecting its behavior are essential and can be considered from different angles (Bergeron et al, 1997). Among the destructive factors, fire is one of the main causes of

useful and effective methods that can provide time and space analysis of natural phenomena, including fire, by providing a suitable time and space coverage and a very low cost (Salamat Nia, 2013). Golestan National Park or Golestan Forest is a protected area in the east of Golestan Province and West of North Khorasan Province. This region is the oldest national park in Iran and an unbelievable haven for its wildlife. It has 1,350 plant species and 302 animal species, including half of Iran's mammalian species in a space around 900 square kilometers. By UNESCO, it is registered as a biosphere reserve in The UNESCO World Heritage Site. Golestan Forest is undoubtedly the most valuable region in Iran, both in terms of quantity and diversity of animal and plant life. The Golestan National Park's biodiversity is even more advanced than some European countries, which are hundreds of times larger than the park. The name of the Golestan province is also selected from this region; therefore, the need for more attention and protection of this region is obvious and unconditional. However, according to statistics available on these forests, every year, due to the fire, there is a lot of damage and a large area of them is destroyed in a short time. With the above reasons, and for many other reasons, it is necessary to develop and produce timely, accurate and documented maps of the affected and damaged areas, as well as to create maps of vulnerable areas with high fire risk. Also, the effects of environmental factors in the occurrence of forest fires is undeniable.
\end{abstract} the destruction of natural ecosystems, which, annually, brings significant damages to these areas. Today, after drought, urban and human activities, fire is one of the most widespread destructive factors of natural ecosystems (Yin et al, 2004).

Fire occurs every year in Iran's forests and pastures, which have different climates and vegetation, most of which are initiated by humans unintentionally (Adeli, 1975). As an ecological factor, fire can be destructive and, at the same time, with a good plan, it is a good solution to the management of ecosystems. Studies on fire management make managers and planners construct more advanced management plans to deal with the crisis (Fule et al, 2006). Satellite imagery and remote sensing techniques are

\section{REVIEW OF THE LITERATURE}

On the simulation and modeling of forest fire, various studies have been carried out in the world and Iran and various models have been developed. In fact, to predict the behavior and propagation of fire, numerous numerical models have been created in different parts of the world that can be integrated into GIS. This section reviews some of the internal and external investigations that have been made. (Salamt Nia, 2013), using GIS methodology and geographic information system, analyzed 
the effective parameters and fire control triggers in Golestan National Park. In this research, Aster satellite images, ETM anf Hyperion satellite images were used and the fire risk and dry and worn carbon indicators (NDLI, CAI, PSRI) were obtained. (Nofarasti et al, 2014), during a simulation study, investigated the propagation of fire in the forest using an automatic cell method, taking into account important environmental factors such as density, foliage, ground height, flammability and wind conditions. Swarm software was also used to simulate the fire propagation behavior in the artificial environment. (Ghaemirad et al, 2016) used Berjak and Hearne's cellular automata model to simulate the fire propagation of the forests of Guilan province. In order to improve the accuracy of the fire-explosion modeling, they determined the coefficients in the above model using two methods of particle swarm optimization (PSO) and colony of bee. The results showed that the bee colony optimization method had better ability to produce optimal parameters of cellular automata model than particle swarm optimization method.

(Yasmia et al, 2008) developed CA-based fire behavior with simple and intuitive transmission rules. This research improves the previous models of cellular automata by using unique transmission rules that can accurately calculate expanded fire within and between cells, as well as alignment of fire with wind direction and slope, with a realistic way. (Valizadeh et al, 2014) evaluated the Kalibar forests in terms of fire risk using fuzzy theory and multi-criteria decision-making algorithm in GIS environment. Landsat 8 OLI satellite images were used for this purpose. Factors such as topography, vegetation, climate, distance from the road and the city and the countryside were considered. The results showed that the south-east and southwest of the region have high potential, and north and northeast have lower potential for forest fire; as well as multi-criteria analysis in the GIS environment was an effective tool for assessing the forest fire. (Tiziano et al, 2015), with the purpose of simulating fire propagation, used lattice techniques so as to remove the problems of the vector-based method. They used the redefinition of the fire speed, which was generally used by the vector-based equations. Then, using corrective factors, numerical optimization was used to find optimal value in the factors. The results were compared with conventional cellular automata, suggesting a higher performance of this model than ordinary cellular automata.

\section{CELLULAR AUTOMATA AND ITS APPLICATION IN THE PROPAGATION OF FIRE}

In recent years, the focus has been on forest fire, which has made progress in simulating and modeling fire management with software to improve fire prevention and risk prevention. Most recent views on the propagation of fire emission are used by cellular automata models (Adeli, 1975). Cellular automata are called mathematical models that are discrete in space and time, and the state of the variables only takes values from a text state. The rules that change the mode of the variables are local and depend only on a small number of neighbors. By adopting a cellular automaton method, one can easily describe a system that has a large number of specific interactions, namely mapping to two-dimensional cellular automata. ${ }^{1}$

The main advantage of this method is that there is a dedicated interaction that can be used in simulation without the need to find a complex mathematical relationship that properly

\footnotetext{
${ }^{1}$ Cellular automata
}

describes the state of the system. To simulate the whole system, we need interaction of each of the variables and the environment for modeling.

The surface of land (forest) can be represented as a CA through a simple division into two-dimensional arrays of square-shaped areas with a length L. In this case, each cell shows a constant region (Fig. 1); and has features that are in accordance with environmental characteristics such as vegetation and ground height. CA is also used for fire propagation modeling, most of which are very simple and lacking in detail about fire and surrounding areas (Sutherland, 1994). In this study, the CA model uses a number of factors in the environment to simulate fire propagationing. Fire expansion is focused on examining the critical density of the bushes, which is determined by the implementation of simulations under different initial conditions of the critical density.
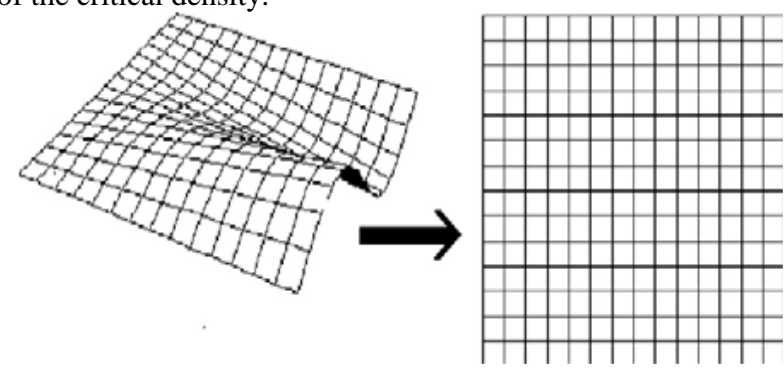

Figure 1. The forest range is presented as similar twodimensional cells

\section{LOCATION OF THE STUDY AREA}

Golestan forest is one of the most important forests in Iran located in the east of Golestan province and west of Eitan, North Khorasan. This forest is one of the tourist destinations in Iran and it crosses several communication routes. According to the statistics, most of the Golestan forest fires have a source of human origin and have been in the vicinity of these roads. Golestan province is about $22033 \mathrm{~km} 2$, between $36^{\circ}$ and $25^{\prime}$ to $38^{\circ}$ and $8^{\prime}$ longitude from the equator and $53^{\circ}$ and $50^{\prime}$ to $56^{\circ}$ and $11^{\prime}$ east longitude from the Greenwich meridian. Its area is larger than 70 countries and 10 other provinces. This province is neighbor to the Republic of Turkmenistan from the north, from the east to Khorasan province, south to Semnan province, and west to Mazandaran province and the sea (Fig. 2).

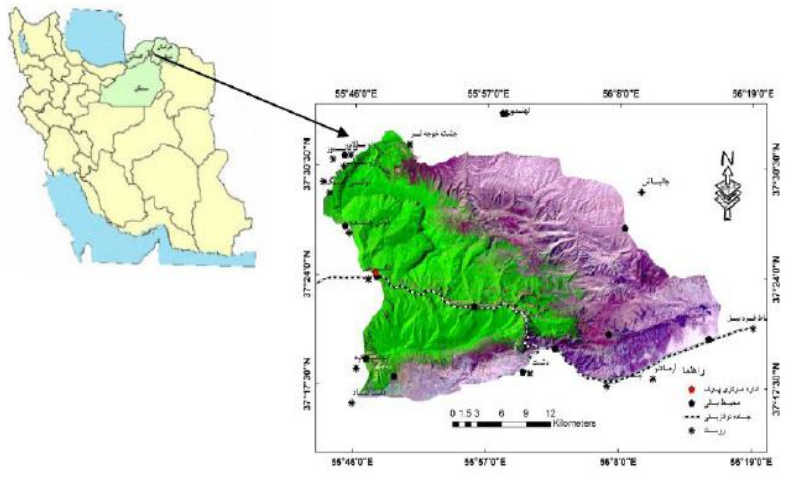

Figure 2. Location of the study area

\section{INTERPRETATION OF THE RESEARCH MODEL}

Forest fires are a dynamic and complex phenomenon. The study of complex fire behavior requires the study of effective and influential factors on it. During various researches, different 
factors have been considered in the way fire propagations. The choice of these factors, on the one hand, depends on the model being used and, from another aspect, the availability of the data. The model used to model fire propagation is based on the model provided by Alexandridis. In this method, the parameters used include vegetation, temperature, ground height, slope, slope direction, road, river and other parameters. For each cell, the probability of ignition is calculated by equation (1).

$$
(\text { Pburn }=P h(1+\text { Pveg })(1+\text { Pden }) P w P s)
$$

Where

Pburn = potential for a cell to burn, $\mathrm{Pn}=$ experimental coefficient, Indicating the probability of a fire propagationing to one of the neighboring cells (Table 1).

This coefficient is calculated under the conditions of wind, topography, type and vegetation.

\begin{tabular}{|c|c|c|c|}
\hline $\mathrm{A}$ & $\mathrm{C}_{1}$ & $\mathrm{C}_{2}$ & $\mathrm{Ph}_{\mathrm{h}}$ \\
\hline $0 / 078$ & $0 / 045$ & $0 / 131$ & $0 / 58$ \\
\hline
\end{tabular}

Table 1. Experimental initial values considered by Alexandridis et al

\subsection{Effect of Earth (Height, slope, slope direction)}

Land-height variations are very effective factors in forest fire propagationing. Always, when the fire slides upwards during a fire, the flame distance decreases rapidly from exhausting fuel, which increases the temperature of the fuel and facilitates the fire of these materials in less time. Under these conditions, the velocity of expansion in the upward direction dramatically increases, but in the downward direction, this is the opposite, and the negative slope causes the flame angle to increase with the fuel, resulting in a dramatic decrease in the rate of fire propagationing in the downward direction.

In this study, the model used to calculate the slope effect is given by (2).

$$
\left(P s=\exp (a) \theta_{z}\right)
$$

$$
\text { Where } \quad \begin{aligned}
\theta_{\mathrm{z}}= & \begin{array}{l}
\text { slope of the land and } \mathrm{a} \text { is an } \\
\text { experimental coefficient. }
\end{array}
\end{aligned}
$$

It should be noted that due to the shape of the cells that are square, the angle of slope is calculated in different ways, depending on whether the two cells are adjacent or diagonal. With this in turn, the angle of slope for adjacent cells is calculated by equation (3).

$$
\left(\theta_{z}=\tan ^{-1}\left(\frac{E_{1}-E_{2}}{l}\right)\right)
$$

Where

$$
\mathrm{E} 1, \mathrm{E} 2 \text { = height of two cells }
$$$$
\mathrm{L}=\text { square cell length }
$$

Also, for the diagonal cells of the slope, equation (4) is used.

$$
\left(\theta_{z}=\tan ^{-1}\left(\frac{E_{1}-E_{2}}{\sqrt{21}}\right)\right)
$$

Figures $(3,4$, and 5$)$ show the altitude, slope and slope direction in the study area.

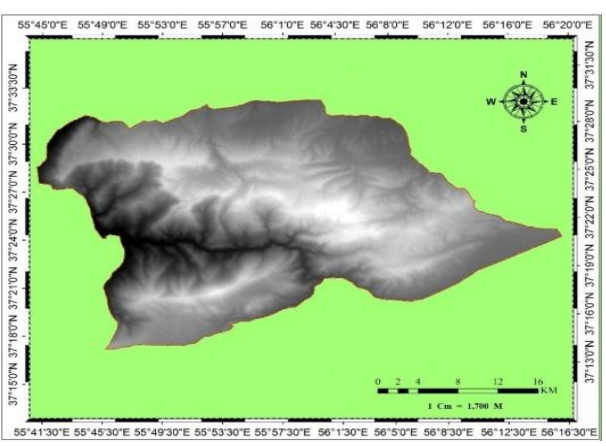

Figure 3. Map of the height changes in the study area

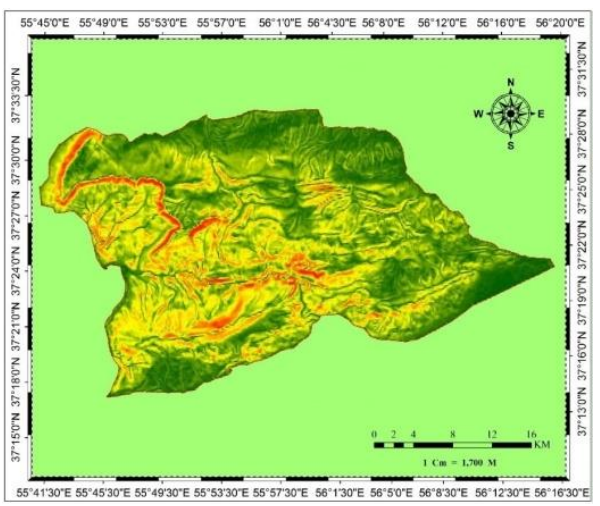

Figure 4. Map of changes in the slope of the study area

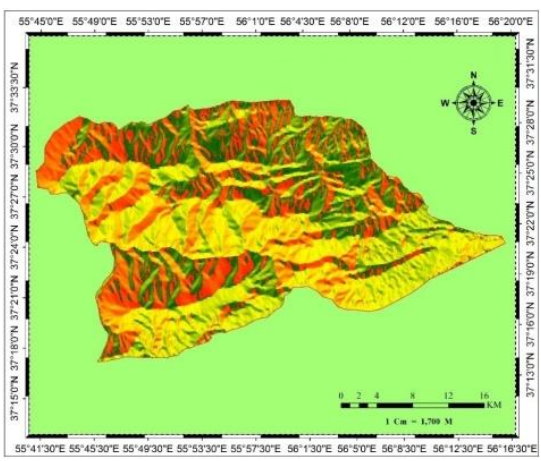

Figure 5. Mapping the direction of slope of the study area

\subsection{Type and density of vegetation cover}

Existing fuel models are mainly used to divide the types of vegetation in the area. In fuel models, the combustion rate of conventional fuels is calculated based on their type and density. In this study, Pveg and Pden coefficients are calculated using Tables (2 and 3). These coefficients are classified based on vegetation and their density [Alexandridisa et al, 2008 ]. The vegetation map of the study area is also shown in Fig. 6. 


\begin{tabular}{|c|c|c|c|}
\hline $\begin{array}{l}\text { Probability } \\
\text { of fire } \\
\text { expansion }\end{array}$ & categories & $\begin{array}{l}\text { Vegetati } \\
\text { on } \\
\text { density }\end{array}$ & $\begin{array}{c}\text { Codes } \\
\text { Pden }\end{array}$ \\
\hline low & Agriculture, forest & $\begin{array}{c}\text { Low } \\
\text { density }\end{array}$ & -0.4 \\
\hline average & $\begin{array}{l}\text { The density is less than } \\
\mathrm{m} 3100 \text { and } 200-100 \mathrm{~m} 3 \\
\text { per hectare }\end{array}$ & $\begin{array}{c}\text { Average } \\
\text { density }\end{array}$ & 0 \\
\hline high & $\begin{array}{c}\text { The density is less than } \\
200-350 \mathrm{~m} 3 \text { and } 350 \mathrm{~m} 3 \\
\text { per hectare }\end{array}$ & $\begin{array}{l}\text { High } \\
\text { density }\end{array}$ & 0.3 \\
\hline
\end{tabular}

Table 2. Categorization of Vegetation Type

\begin{tabular}{|c|c|c|c|}
\hline $\begin{array}{c}\text { Probability } \\
\text { of fire } \\
\text { expansion }\end{array}$ & Type of vegetation & $\begin{array}{c}\text { Types of } \\
\text { vegetati } \\
\text { on }\end{array}$ & $\begin{array}{c}\text { Codes } \\
\mathrm{P}_{\text {veg }}\end{array}$ \\
\hline Low & Agriculture, uncovered & $\begin{array}{c}\text { Resistan } \\
\text { t to fire }\end{array}$ & -0.3 \\
\hline Average & Oak, Free_oak & $\begin{array}{c}\text { Semi- } \\
\text { resistant } \\
\text { to fire }\end{array}$ & 0 \\
\hline High & $\begin{array}{c}\text { Protective, Hornbeam, } \\
\text { Rush, Hornbeam, } \\
\text { Eveam, Hornbeam, } \\
\text { Evangelical, } \\
\text { Bush }\end{array}$ & $\begin{array}{c}\text { Sensitiv } \\
\text { e to fire }\end{array}$ & 0.4 \\
\hline
\end{tabular}

Table 3. Distribution of Vegetation Concentration

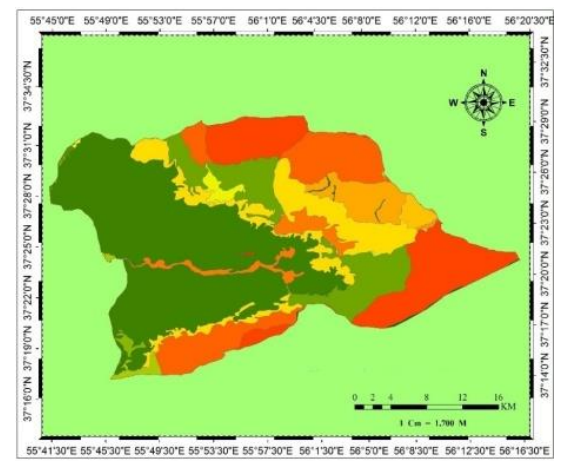

Figure 6. Vegetation map of the study area

\subsection{Roads}

Since humans increase the frequency and distribution of fire during their transportation, and roads provide access to areas and increase the risk of fire, therefore, the roads can be one of the parameters that affect forest fires. The position of the road in the studied area is visible in Fig. 7.

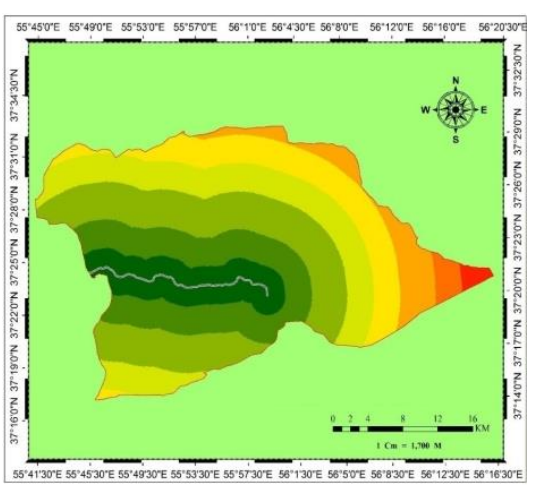

Figure 7. Map of the location of roads in the study area

\subsection{Rivers}

Considering that tourists and hunters may gather around the river and because humans are one of the causes of the fire, so the proximity to the rivers can increase the forest fires, so the location of the rivers in the studied area can be seen in Fig. 8.

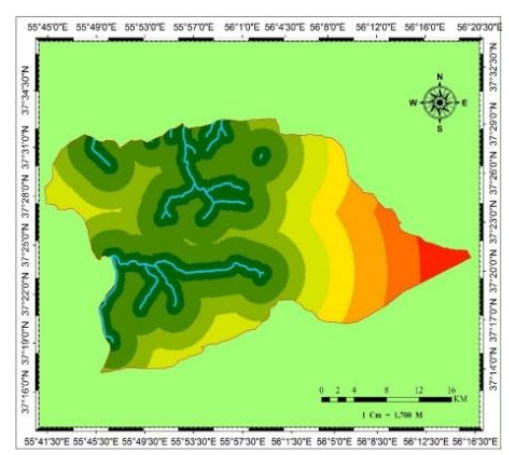

Figure 8. Map of the position of the rivers in the studied area

\subsection{Temperature}

As it is expected that there is a higher probability of fire and the number of fire occurrences in areas with higher temperatures, isothermal lines were used in this study as another important factor in the propagation of fire (Fig. 9).

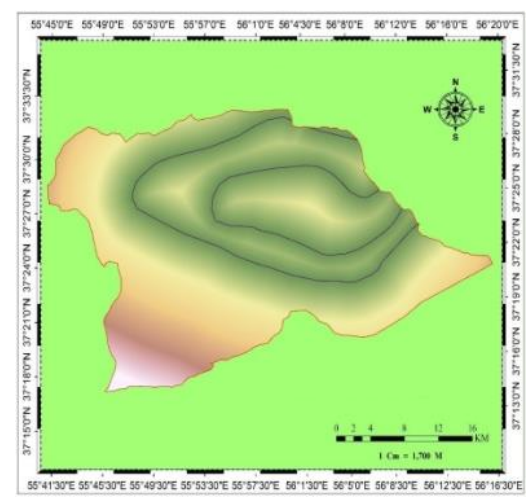

Figure 9. Isothermal lines map in the study area 


\subsection{The speed and direction of the wind}

The modeling of forest expansion based on wind speed and direction is one of the challenges. So far, there is no model that can model wind effects well, because, wind, as a fluid, has very complex behavior, especially in slope lands. The effect of wind on earthquake is a subject that is still under investigation. In various investigations, many experimental relationships have been proposed to model the effect of wind speed and direction on the speed and direction of fire propagationing. In this study, a more flexible model and better simulation results were used. Equation (5) presents the proposed model for calculating the wind effect on forest fire distribution modeling (Alexandridisa, 2008).

$$
(P w=\exp (c 1 V) f t)
$$

Where

$$
\begin{aligned}
\mathrm{C} 1 & =\text { experimental coefficient } \\
\mathrm{V} & =\text { wind speed in } \mathrm{m} / \mathrm{s} . \\
\mathrm{ft} & =\text { calculated from equation } 6 .
\end{aligned}
$$

$(f t=\exp (V c 2(\cos (\theta)-1)))$

In equation (6), theta is the angle between the direction of propagation of the fire and the wind direction, and $\mathrm{C} 2$ is the experimental coefficient. In this regard, the wind direction can have any continuous values between 0 and 360 degrees. However, in many models used in other studies, the wind direction can only have a few discrete numbers.

5. Determine the expansion of the fire direction

The integration of cellular automation and the empirical model allows for the expansion of the fire to be considered at an early stage. In this research, using the Moore neighborhood model, the Golestan forest fire distribution model was developed. Several modes were considered to predict Golestan forest fire propagation.

Mode one: The cell does not contain combustible materials. In this case, the cell can not burn at any time. Residential areas, rivers and roads are part of this situation.

Mode two: The cell contains the fuel, but it is still not burnt.

Mode three: the cell is burning.

Mode four: the cell is completely burnt.

These states for all cells may occur. Therefore, local automated cellular laws are used to enforce the rules to the neighboring cells of the central cell. According to Figure 10, local laws include the following rules.

If cell mode $(\mathrm{i}, \mathrm{j})$ at time $\mathrm{t}$ is 1 , cell mode will be 1 at time $\mathrm{t}+1$. These rules indicate that if a cell contains no fuel, it will not be fueled at any stage and will always have a constant value of 1 .

If the cell mode ( $i, j)$ at time $t$ is 3 , then cell mode will be 4 at time $t+1$. This law states that if the fuel cell is burning at this stage, it burns in the next step completely and is considered as the burned cell and takes code 4 .

If the cell mode $(i, j)$ at time $t$ is equal to 4 , then the cell mode at time $t+1$ will also be 4 . This rule states that if the cell is burned, that is, it has been burned in the previous stages, due to lack of new fuel, it will be the same burned cell.

If the mode of the cell $(i, j)$ at time $t$ is 3 , then the mode of the cells $(j+1, i+1)$ at time $t+1$ is equal to 3 with Pburn probability. This transfer law is the most important local transfer law. In fact, the underlying foundation for local cellular transmission rules is the origin principle. Based on this rule, if a cell is in a burning mode (at step t), then, according to the Moore neighborhood, 8 neighboring cells are also exposed to combustion. Which neighboring cell will be combusted in the next step, is calculated according to (1).

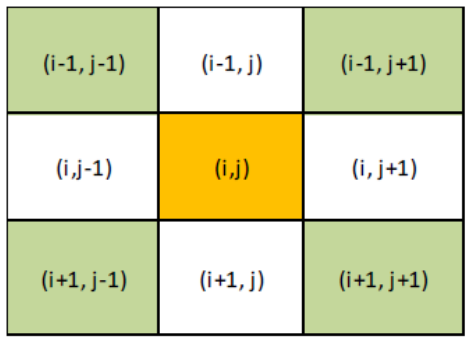

Figure 10. Central cell and its Neighborhood

All the steps described by cell automation are carried out simultaneously, each time the cellular automation scheduling is examined, the burning cells are examined and its effect on eight neighboring cells is checked in accordance with the local transfer rules. Each cell will adopt a number from 0 to 1 according to the number 4 rule, where the time mode is also a dynamic representation of the fire frontier. A review of the total cell automation space in its time intervals shows the dynamic display of the propagation of fire based on the factors affecting it. At this point, actual fire periods are also calculated. The issue that is noticeable here is the fact that cellular automation intervals differ from actual fire time periods. There is no connection between these two times. The time frame of cellular automation is bound to the cellular space and is dependent on the area of the region.

\section{EVALUATION OF RESULTS}

In order to evaluate the quality of the fire propagation model in the Golestan forest, the Polygon of the fire propagation (output of the cellular automation model) was compared with real fire polygon. For this purpose, the polygon for the propagation of fire from cell automata was compared with the real polygon (Fig. 11). Also, in order to evaluate the accuracy of the fire distribution model, the overall accuracy and Kappa index were used. By comparing the results of fire propagation modeling with real fire information, the output error matrix was obtained according to table (4). In this matrix, the rows represent reality, and the columns represent the output of the simulation. Moreover, the numbers on the main diameter represent the consistency of the number of burnt and unburned pixels in simulation and reality. Table 5 shows the overall accuracy obtained from the fire propagation model and the calculated Kappa Index. 


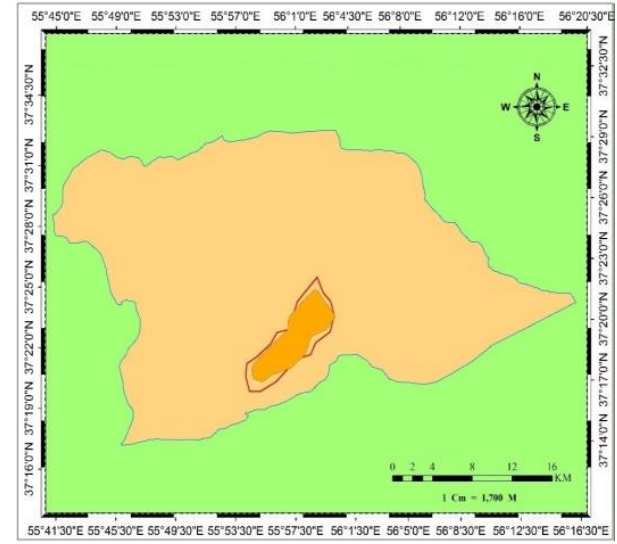

Figure 11. Simulated and real fire propagation maps

\begin{tabular}{|c|c|c|c|c|}
\hline \multicolumn{2}{|c|}{} & \multicolumn{3}{c|}{ simulation } \\
\cline { 2 - 5 } & burned & unburned & Total \\
\hline \multirow{4}{*}{ real } & burned & 7171 & 229 & 7250 \\
\cline { 2 - 5 } & unburned & 3020 & 25986 & 18856 \\
\cline { 2 - 5 } & total & 10041 & 16065 & 25956 \\
\hline
\end{tabular}

Table 4. Reading error matrix from comparing actual fire data and model output

\begin{tabular}{|c|c|c|c|}
\hline $\begin{array}{c}\text { Total } \\
\text { accuracy }\end{array}$ & $\begin{array}{c}\text { Kappa } \\
\text { index }\end{array}$ & $\begin{array}{c}\text { Actual burned } \\
\text { area (hectare) }\end{array}$ & $\begin{array}{c}\text { Predicted burned } \\
\text { area (hectare) }\end{array}$ \\
\hline 0.65 & 0.59 & 444.59 & 617.13 \\
\hline
\end{tabular}

Table 5. Results of comparison of real and simulated fire information

5.1.1 Summaries and Conclusions: The present study was conducted to intelligently manage the occurrence and expansion of Golestan forest fires in GIS environment using cellular automata rules. The purpose of this study was to provide an appropriate model for forecasting the propagation of fire in the forests of the investigated area for intelligent fire fighting managment. In order to implement the fire-propagation model with cellular automation, the actual fire area that previously occurred in the area under study was selected. The implementation of all phases of fire propagationing by cellular automata was carried out simultaneously. Finally, the fire propagation was determined by selecting the starting point for the fire according to the ideas of experts of natural resources and foresters. Eventually, after the completion of the implementation of the cellular automata model to simulate the propagation of the fire within the scope of the study, the final polygon form of the fire propagation was obtained. In order to compare the simulated realistic fire propagation, the fire propagation polygon was compared with the real polygon. The results showed similar simulated and real fire propagation polygons that once again identified the applicability of the model to identify the fire propagationing front.

In order to quantitatively evaluate the accuracy of the used fire propagation model, the number of burned and healthy cells in the simulated and real models (the percentage of correct and incorrect model samples) were compared and the error matrix was obtained. In the error matrix, the original diameter numbers represent the consistency between the number of burned and unburned pixels in simulation and reality. In the resulting error matrix, the first number on the original matrix diameter (7171) indicates that the number of pixels are burned both in modeling and in reality, in other words, the model predicted a total of 7171 pixel pixels according to reality. Finally, the error matrix gave two kinds of accuracy: overall accuracy and kappa index. The overall accuracy is very optimistic considering the fact that it is calculated with the ratio of the correct number of pixels to the total number of pixels; As the number of pixels that are wrongly predicted were not considered. According to Table 5, the overall accuracy of the fire propagation model in this study is equal to $65 \%$, which is acceptable and reflects the utility of the fire propagation model based on cellular automata. The Kappa calculated for the fire propagation model is also $59 \%$. Given that this index, in contrast to the general accuracy, also takes into consideration the pixels that are not well-predicted and applies in the calculation, it provides a pessimistic mode for calculating the accuracy of the model.

The results of the study showed that the cellular automation method had a great potential for intelligent management of the occurrence and expansion of the fire frontier in the forests of the area. Therefore, it can be used to predict how the fire propagations in the forests of the area. The cellular automation makes it possible to investigate the fire propagation at an instant at a time; therefore, the proposed model can be used as a decision support system for intelligent fire suppression management, better fire control and optimal allocation of forces and facilities at appropriate fire places; Because, a decision support system for forest fire propagationing modeling is an integral part of environmental management units. In this regard, the existence of a system that can predict the propagation of forest fires both locally and in terms of time will greatly facilitate forest fire management.

\section{REFERENCES}

Adeli, A., 1975. Forest support. Publishing and Printing Institute of Tehran University, Tehran, p. 279

Adeli, E. Yakhkeshi, A., 1975. "Forest Support", Tehran University Publishers.

Alexandridisa. A et al., 2008 "A cellular automata model for forest fire spread prediction: The case of the Wildfire that swept through Spetses Island in 1990," Applied Mathematics and Computation, vol. 204, pp. 191-201,.

Bergeron, Y., Harvey, B., 1997. Basing silviculture on natural ecosystem dynamics: an approach applied to the southern boreal mixed wood forest of Qu.

Collins, R., Neufville, R., Claro, J., Olivera, T., P.Pacheco, A. (2013). Forest fire management to avoid unintended consequences: A case study of Portugal using system dynamics. Journal of Environmental Management, 130, 1-9.

Fule, P., Ribas, M., Gutierrez, E., Vallejo, R. and kaye,M., 2006. Forest structure and fire history in an old pinus nigra forest, eastern Spain. Forest Ecology and Management, 241(3): $79-88$. 
Ghaemirad, T., Karimi, M., 2016. Performance Evaluation of Forest Fire Extension Modeling Approaches with Using Cellular Automata(Case Study: Guilan Forests)

Kim, J.W., Jung, C.E., 2008. Abundance of soil microarthropods associated with forest fire severity in Samcheok, Korea. Journal of Asia Pacific Entomology Entomol, 11, $77-81$.

Nofaresti, S,. Tabrizi.T,. Qamarnaz.2014. Application of Cellular Automata in Fire Emission Simulation, First National Conference Software Engineering, p. 319-327.

Oliveira, T., 2005. The Portuguese National Plan for Prevention and Protection of Forest against Fires:the First Step. International Forest Fire News, Lisbon, Portugal, 30 - 34.

Penttila, R., Junninen, K., Punttila, P., Siitonen, J., 2013. Effects of forest restoration by fire on polypores depend strongly on time since disturbance- A case study from Finland based on a 23-year monitoring period. Forest Ecology and Management, 310, 508 - 516.

Salamat Nia. M. 2013. The application of satellite imagery processing in Forest Forest Assessment in Golestan National Park,Dissertation for Master Degree in Remote Sensing and Geographic Information Systems, Aras International Campus, Tabriz University, Faculty of Geography, By Dr. Khalil Valizadeh Kamran.

Shorohova, E., Kuuluvainen, T., Kangur, A., Jogiste, K., 2009. Natural structures, disturbance regimes and successional dynamics in the Eurasian boreal forests: a review with special reference to Russian studies. Annals of Forest Science, 66 (2), 201.

Sutherland, B.R. and Jacobs, A.E., 1994. "Self- Organization and Scaling in a LatticePredator-Prey Model", Complex Systems Vol 8: 385-405.

Swengel, A.B., 2001. A literature review of insect responses to fire, compared to other conservation managements of open habitat Biodivers. Conserv. 10, 1141 - 1169.

Tiziano. Gh., Bachisio. A., Grazia, P. and Pierpaolo, D., 2015. An Improved Cellular Automata for Wildfire Spread, Department of Mechanical, Chemical and Materials Engineering.

Yassemia, S., et al., 2008. Design and implementation of an integrated GIS-based cellular automata model to characterize forest fire behaviour.

Yin, h., Kong, F. H. and Li, X. Z., 2004. RS and GISbased forest fire zone mapping in Dahinggan Mountains. Chinese Geographical Science 14 (3): 251-257. 